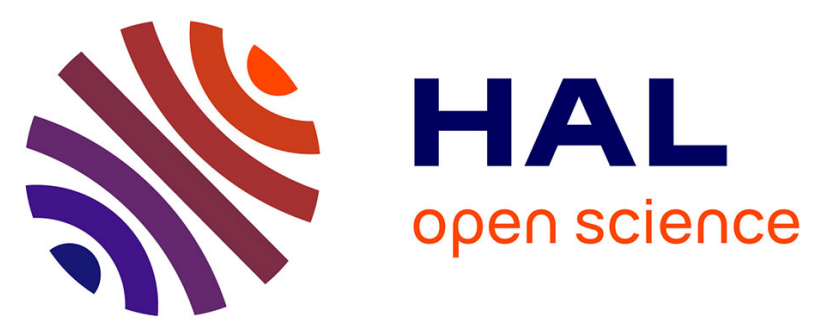

\title{
In situ monitoring of corrosion processes by coupled micro-XRF/micro-XRD mapping to understand the degradation mechanisms of reinforcing bars in hydraulic binders from historic monuments
}

Sophie Grousset, Florian Kergourlay, Delphine D. Neff, E. Foy, J. L. Gallias, S. Reguer, A. Noumowe, Philippe Dillmann

\section{To cite this version:}

Sophie Grousset, Florian Kergourlay, Delphine D. Neff, E. Foy, J. L. Gallias, et al.. In situ monitoring of corrosion processes by coupled micro-XRF/micro-XRD mapping to understand the degradation mechanisms of reinforcing bars in hydraulic binders from historic monuments. Journal of Analytical Atomic Spectrometry, 2015, 30 (3), pp.721-729. 10.1039/C4JA00370E . hal-01187814

\author{
HAL Id: hal-01187814 \\ https://hal.science/hal-01187814
}

Submitted on 17 Nov 2015

HAL is a multi-disciplinary open access archive for the deposit and dissemination of scientific research documents, whether they are published or not. The documents may come from teaching and research institutions in France or abroad, or from public or private research centers.
L'archive ouverte pluridisciplinaire HAL, est destinée au dépôt et à la diffusion de documents scientifiques de niveau recherche, publiés ou non, émanant des établissements d'enseignement et de recherche français ou étrangers, des laboratoires publics ou privés. 


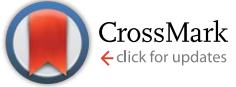

Cite this: J. Anal. At. Spectrom., 2015, 30,721

\section{In situ monitoring of corrosion processes by coupled micro-XRF/micro-XRD mapping to understand the degradation mechanisms of reinforcing bars in hydraulic binders from historic monuments}

\author{
S. Grousset, ${ }^{a}$ F. Kergourlay, ${ }^{b}$ D. Neff, ${ }^{\star a}$ E. Foy, ${ }^{a}$ J.-L. Gallias, ${ }^{b}$ S. Reguer, ${ }^{c}$ P. Dillmann ${ }^{a}$ \\ and A. Noumowéb
}

\begin{abstract}
Historic monuments have been partly built since antiquity with iron or steel reinforcements sealed in mortars or hydraulic binders. But the presence of chloride in the environment can weaken the structures due to the corrosion of these metallic parts, leading to the cracking of the binder. In this context, in order to better understand the first steps of these corrosion mechanisms a chemical cell was designed to operate in situ analyses of the phases precipitated when a chlorinated solution is introduced in the vicinity of the bar. The chemical and structural characterization (micro-XRF and micro-XRD respectively) was performed under synchrotron radiation at the SOLEIL-DiffAbs beamline. Moreover, complementary SEM-EDS analyses were carried out before and after the in situ cell experiment in order to determine the final localisation of the corrosion products inside the crack network. The results show that iron can spread up to $1 \mathrm{~mm}$ away from the metallic bar inside the pores of the binder after $44 \mathrm{~h}$ of corrosion. Moreover, in accordance with laboratory experiments conducted in solution in the presence of $\mathrm{Fe}^{2+}$ and $\mathrm{Cl}^{-}$ions the reaction pathways conduct to the successive formation of an intermediate $\mathrm{Fe}(\mathrm{II})-\mathrm{Fe}($ (II) chlorinated green rust which transforms into ferric oxyhydroxides such as akaganeite or goethite depending on the local concentration of iron.
\end{abstract}

Received 30th October 2014 Accepted 5th January 2015

DOI: $10.1039 / c 4 j a 00370 e$

www.rsc.org/jaas particular, damage due to corrosion of the iron reinforcements in these binders is critical. The degradation of the monument is visible through the cracking and spalling of the binder. ${ }^{5-7}$

In order to overcome such problems, the conservation approach consists of three main lines of action: first, the identification of the conservation state, then, the prediction of the iron corrosion and last, the development of adapted conservation strategies. ${ }^{8}$

The corrosion processes of reinforced concrete and hydraulic binders are explained by a variation of the chemical conditions. The initial alkaline conditions within the binders allow the formation of a passive and protective layer on the iron avoiding further corrosion. However, a decrease of the solution $\mathrm{pH}$ during binder carbonation, ${ }^{9}$ and/or the progression of aggressive chemical species such as chloride ions towards the reinforcement $t^{10}$ can lead to the destabilization of the passive layer and let corrosion occur. Corrosion processes imply the formation of corrosion products which can generate crack and binder spalling caused by high tensile stresses generated in the medium. ${ }^{11,12}$

In particular, laboratory experiments on steel bars corroded in a chlorinated concrete under various conditions have shown
LAPA: NIMBE, SIS2M UMR3299 CEA/CNRS and IRAMAT UMR5060 CNRS, CEA Saclay, 91191 Gif sur Yvette Cedex, France. E-mail: delphine.neff@cea.fr

${ }^{b}$ L2MGC, University of Cergy-Pontoise, 95000 Cergy, France

'Synchrotron SOLEIL, Saint-Aubin BP48, 91192 Gif-sur-Yvette, France 
that the corrosion layers observed were mainly composed of non-chlorinated phases, magnetite $\left(\mathrm{Fe}_{3} \mathrm{O}_{4}\right)$ and goethite $(\alpha$-FeOOH). Cl-containing phases like ferrous hydroxychloride $\beta-\mathrm{Fe}_{2}(\mathrm{OH})_{3} \mathrm{Cl}$ were only observed deep in the needle-like pits. ${ }^{13}$ Although it is well known that chloride ions participate in the steel depassivation leading to pit formation, their role in the advanced stages of iron corrosion in binders is not well understood. ${ }^{14}$ It has been supposed that transient phases of lower density form, causing an increase of the binder cracking phenomenon. ${ }^{15}$

The aim of the present study was to better understand the first steps of the corrosion processes occurring on steel reinforcements in mortar exposed to chlorinated environments in order to (i) determine the location of the corrosion processes, (ii) identify the transient corrosion products and their evolution with time: the roles of intermediate iron corrosion products, particularly chlorine-containing ones, have yet to be revealed, and (iii) highlight the physico-chemical conditions allowing the ferrous species to transport within the porous binder system. Previous in situ studies using X-ray fluorescence have highlighted that the diffusion of elemental iron among other elements can be followed for several hours. ${ }^{16,17}$ In the present study, a combination of X-ray fluorescence and diffraction was designed in order to collect both the compositions and chemical structures of the phases formed in situ at the micrometric scale. In this way, a dedicated cell replicating a steel bar inside a Portland cement mortar was achieved to perform in situ structural and elementary analyses during the corrosion process. The analytical approach proposed here is based on the use of complementary micro-beam techniques to deliver data on the local chemical composition and crystalline structure: Scanning Electron Microscopy and Energy Dispersive Spectroscopy (SEM-EDS), X-ray diffraction and X-ray fluorescence spectroscopy using a micro-beam (labelled micro-XRD and micro-XRF respectively). The latter was conducted on both a laboratory set-up and under synchrotron radiation in order to adjust the time and scale resolutions during the in situ experiments. In addition, global observations were consigned concerning the diffusion of water and the variation of the $\mathrm{pH}$ in order to understand the processes occurring during the experiment.

\section{Methodology}

\section{Experimental cells}

Cells composed of mortar and bare steel bars were studied. Mortar was chosen because of its similarity to the materials employed in ancient building. ${ }^{18}$ The mortar was prepared with a water-cement ratio of 0.5 and a sand-cement ratio of 3 using a CEMI 52.5 N CP2 cement type. The cells were designed following the protocol presented below (Fig. 1). First, the steel bar $(\Phi=1 \mathrm{~cm}, H=12 \mathrm{~cm})$ was maintained vertically at the center of a cylindrical plastic mold $(\Phi=3 \mathrm{~cm}, H=12 \mathrm{~cm})$. Along the bar, a multifilament glass yarn $(\Phi=2 \mathrm{~mm}, H=12 \mathrm{~cm})$ was fastened. The mortar was cast in the mold and the whole system was dried for 28 days at ambient conditions. After that, the plastic mold was removed, the obtained cylinder was embedded

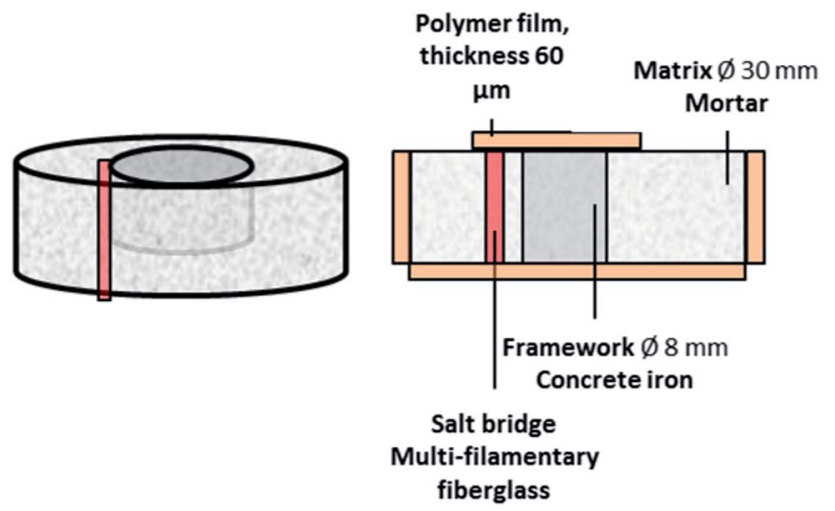

Fig. 1 Schematic diagram of the in situ cell; perspective view (left), transverse view (right).

in epoxy resin before sections of 1 centimeter thickness were cut with a diamond wheel saw to prepare the cells in cross section mode.

Each cross section was prepared as follows: it was first ground with SiC papers and then polished with a $3 \mu \mathrm{m}$ diamond paste under ethanol. On the front of the cells an adhesive polymer film was applied in order to avoid air penetration through the observation side, but without obstructing the micro-XRD and micro-XRF analyses. For the experiment the cells were wetted by capillarity through the glass filament trapped in the binder in the vicinity of the steel bar, ensuring the penetration of the chlorinated solution at the binder/iron interface.

A solution of $\mathrm{NaCl}$ of $0.5 \mathrm{M}$ concentration was used in order to simulate a seashore environment. The solution was injected into the cell using a syringe, the needle of which was inserted in the multifilament glass yarn at the cells' back until the absorption front appearing in the front of the cell was stabilised.

The analytical methodology was conducted as explained in the following. First, at the macroscopic scale a mapping was realized on the front of the cell using SEM-EDS analysis to determine the composition of the major and minor elements around the steel bar. Then, the cells were wetted as described above and the penetration of the solution was assessed by macrophotography. In addition, the $\mathrm{pH}$ change was evaluated using $\mathrm{pH}$ papers placed on the front of the cell. The strong capillary absorption of the chlorinate solution by the multifilament yarn close to the steel bar allowed the transport of enough chlorinated solution to wet all the interface between the mortar and steel bar as shown by visual monitoring of the progression of the capillary absorption and, in this way, created favorable conditions for iron corrosion. The cells were then put on the analytical in situ set-up to carry out in situ elementary and structural monitoring using the combination of micro-XRD and micro-XRF. Table 1 summarises the in situ analyses of the three cells presented in this paper. The detailed protocol is described hereafter. Table 1 also summarises the conditions of preparation and analyses of the three cells presented here. 
Table 1 Conditions and duration of the in situ acquisitions

\begin{tabular}{lll}
\hline Cell & In situ analyses & $\begin{array}{l}\text { Duration of the } \\
\text { in situ measurements }\end{array}$ \\
\hline C09-C04 & $\begin{array}{l}\text { Micro-XRD + micro-XRF } \\
\text { on the laboratory set-up } \\
\text { Micro-XRD + micro-XRF } \\
\text { C07-C01 }\end{array}$ & $24 \mathrm{~h}$ \\
C02-E03 & $\begin{array}{l}\text { Micro-XRD + micro-XRF, } \\
\text { under synchrotron radiation }\end{array}$ & $65 \mathrm{~h}$
\end{tabular}

After the cells were dried in air, SEM-EDS analyses were carried out to determine the precipitation zones of the iron phases in the pores of the mortar/steel interface.

The morphology was observed using optical microscopy and SEM (acceleration voltage $15 \mathrm{kV}$ ), and the compositions were determined by EDS. EDS detection was carried out with a silicon drift detector allowing oxygen to be quantified with an error of $2 \%$ and other elements under $0.5 \mathrm{wt} \%$ with $1 \%$ of error.

\section{In situ characterization protocol}

Micro-XRD and micro-XRF analyses were performed on two complementary set-ups. The first one is a laboratory rotating anode that allowed the cell design to be tested and experiments of more than 100 hours to be performed. An XRD measurement lasts at least one hour and a half with such a disposal. Consequently, to determine the first step phases formed during the corrosion process, a shorter acquisition time is needed. That's why a second set-up for the in situ monitoring of the corrosion layer's structural evolution was achieved on the DiffAbs beamline $^{19}$ at Synchrotron SOLEIL. The advantage of such analyses is to acquire XRD and XRF maps in order to locate the phases formed during the corrosion process and show their local heterogeneity.

Set-up on a rotating anode X-ray generator. For the microXRD measurements, a Mo anticathode of a rotating anode X-ray generator delivered a monochromatic beam at $17.48 \mathrm{keV}$ focused to a $50 \mu \mathrm{m} \times 30 \mu \mathrm{m}$ surface (flux of about $10^{6} \mathrm{ph} \mathrm{s}^{-1}$ ) using a Xenocs ${ }^{\circledR}$ FOX2D Mo 25_25P diffraction optic (Fig. 2). This optic is a curved mirror with graded multilayer coatings that monochromatizes the incident beam from a single reflection. The cells were placed at an angle of $3^{\circ}$ from the incident beam in order to work in reflection mode, and the spot size at the sample surface was about $1000 \mu \mathrm{m}$ (horizontal finger print due to incident angle) $\times 30 \mu \mathrm{m}$. Diffraction patterns were collected during about $1 \mathrm{~h} 30 \mathrm{~min}$ using a two-dimensional detector (image plate). Data processing was carried out with the EVA software and the ICDD-JCPDS database. XRF analysis was acquired using a silicon drift detector.

The DiffAbs beamline at SOLEIL. The main optical system of the DiffAbs beamline consists of a fixed-exit $\mathrm{Si}(111)$ double crystal monochromator and provides a sagittal focusing (in the horizontal plane) of the monochromatic beam at $17 \mathrm{keV}$ (Fig. 3). In addition, two long mirrors collimate and focus the beam in the vertical plane allowing harmonic rejection and improving

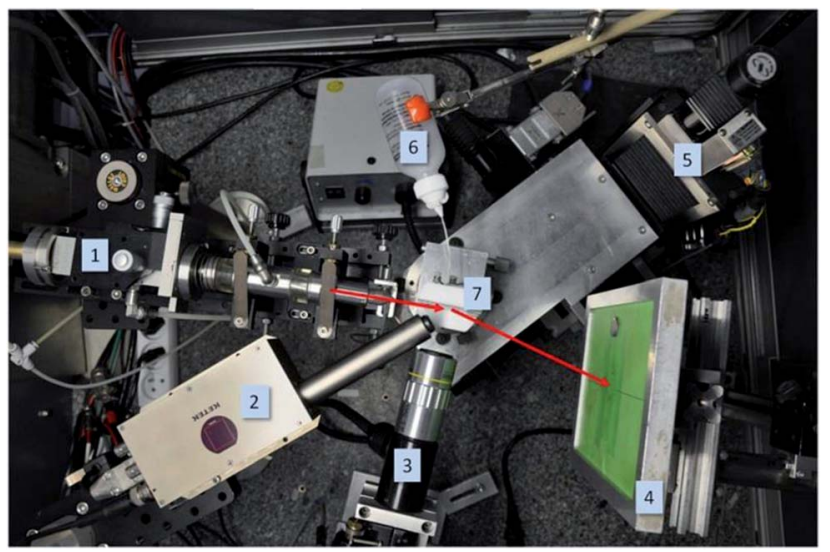

Fig. 2 The in situ monitoring set-up on a rotating anode $X$-ray generator: 1. X-ray (Mo, $\lambda_{K \alpha}=0.709 \AA$ ). 2. XRF detector, 3. OM, 4. image plate, 5. translation table, 6 . chlorinated solution, 7. cell.

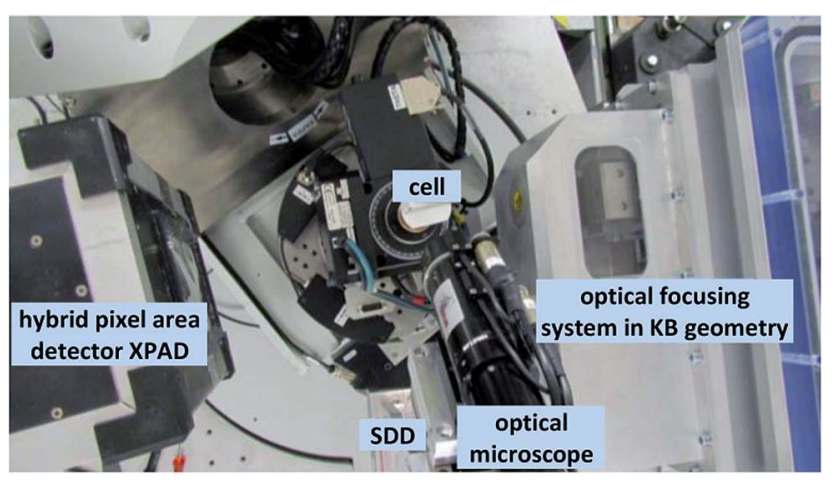

Fig. 3 The DiffAbs experimental set-up at the Synchrotron SOLEIL

the energy resolution. A secondary optical system that consists of two trapezoidal shaped flat and orthogonally placed curved mirrors under grazing incidence (in Kirkpatrick Baez geometry) was used for the present experiment to focus the beam down to $10 \times 10 \mu \mathrm{m}^{2}$ with a flux of about $10^{10}$ to $10^{11} \mathrm{ph} \mathrm{s}^{-1}$. The cell was placed under the beam with an incident angle of $5^{\circ}$, implying a beam size finger print of about $150 \mu \mathrm{m} \times 10 \mu \mathrm{m}(H \times V$ fwhm $)$ on the sample.

A SDD 4Elements detector was used to collect the micro-XRF data. In addition, thanks to the rapid acquisition obtained by coupling the very great brightness of the synchrotron source and the temporal performance of the pixel hybrid XPAD

Table 2 Diffraction peaks and JCPDS files used for the XRD mapping

\begin{tabular}{lll}
\hline Phase & $\begin{array}{l}\text { JCPDS } \\
\text { file }\end{array}$ & $\begin{array}{l}\text { Diffraction } \\
\text { peak }(h k l)\end{array}$ \\
\hline $\begin{array}{l}\text { Akaganeite } \beta \text {-FeOOH } \\
\text { Chlorinated green rust }\end{array}$ & $01-080-1770$ & $(101)$ \\
{$\left[\mathrm{Fe}_{3}{ }^{\mathrm{II}} \mathrm{Fe}{ }^{\mathrm{III}}(\mathrm{OH})_{8}\right]^{+}\left[\mathrm{Cl} \cdot n \mathrm{H}_{2} \mathrm{O}\right]^{-}$} & $00-040-0127$ & $(006)$ \\
$\mathrm{Goethite} \alpha-\mathrm{FeOOH}$ & $00-029-0713$ & $(110)$
\end{tabular}

00-029-0713 
detector, ${ }^{20}$ micro-XRD distribution maps of the corrosion products formed during the penetration of the chlorinated solution were established. The methodology to obtain the micro-XRD maps can be described as follows:

- An Area Of Interest (AOI) is selected using an optical microscope and XRF measurements, and micro-XRD acquisitions are collected on the AOI using the XPAD detector on a defined dimension. For the studied cell C02-E03, a first map of $1.1 \times 0.9 \mathrm{~mm}^{2}$ and, after $32 \mathrm{~h}$ of treatment, a second map on a farther $1.1 \times 1.8 \mathrm{~mm}^{2}$ extended zone were acquired with a step of $100 \times 30 \mu \mathrm{m}^{2}(H \times V)$ and an acquisition time of $10 \mathrm{~s}$ per step on the same region during $65 \mathrm{~h}(=80 \mathrm{~min}$ per map and 44 maps acquired). Each step contains 1 diffraction image.

- After a set of geometrical and intensity corrections, the diffraction diagrams are obtained from the circular integration of the 2D XRD images.
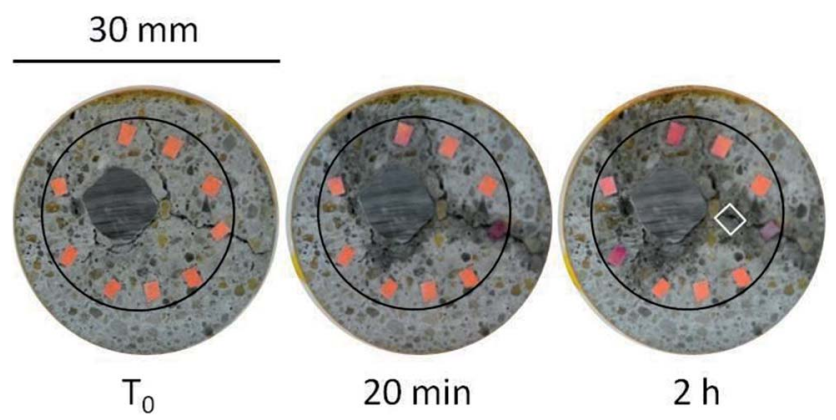

Fig. 4 Cell C02-E03, monitoring of the capillary penetration of a chlorinated solution $(0.5 \mathrm{M} \mathrm{NaCl})$.
- The area evolution of a single diffraction peak per phase is monitored to obtain maps of the phases' distribution. The peaks selected for each phase are reported in Table 2.

\section{Results}

The penetration of the solution was assessed using macrophotography. This monitoring of the capillary penetration of the chlorinated solution (Fig. 4) showed a propagation from the inert multifilament yarn to the binder all around the steel/ mortar interface. For the three studied cells, the stabilization of the propagation front, i.e. when no macroscopic evolution of the migration front is observed when a drop of solution is added, is comprised between 1 and 4 hours. These different values are due to the variable mortar porosity between the different cells, despite the same preparation conditions. The macroscopic cracks present in the cell because of the shrinkage of the mortar during dry curing seem to facilitate the fast and long-distance spreading of the chlorinated solution in the mortar.

The color change of the $\mathrm{pH}$ indicator strips placed on the surface of the cell indicates a pH of around 13 in the zones saturated by the solution. These initial alkaline conditions were expected since the pore water is in equilibrium with each of the solid phases present in the cementitious material. The chemical maps collected by SEM-EDS on the non-treated cross-sections (Fig. 6) indicate that initially, except in the metal, iron is not detected on the three cells, even in the vicinity of the steel bar. From these maps, areas were selected for the monitoring of $\mathrm{Fe}$ transport by micro-XRF and phase evolution by micro-XRD on the laboratory rotating anode set-up. The results obtained in the three cells are very reproducible.

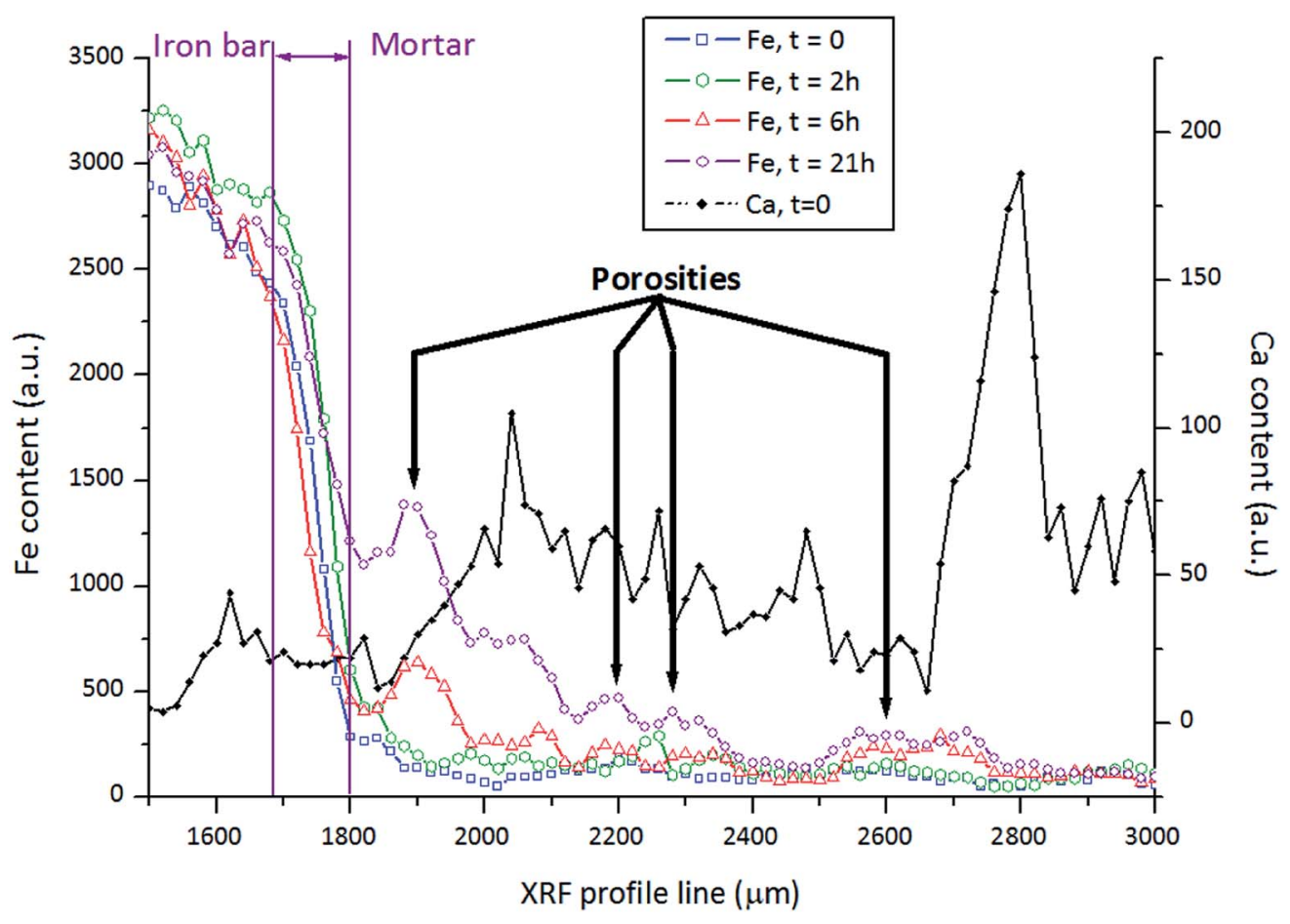

Fig. 5 Cell C09-C04, the micro-XRF profiles obtained with the laboratory set-up. 
Iron content profiles obtained on the C09-C04 cell at various durations of experiment are presented in Fig. 5. The profile obtained at $t=0$ shows the initial location of the rebar. The fact that the decrease does not form a sharp step is due to the size of the beam, enlarged horizontally because of the low incidence angle set-up. The $600 \mu \mathrm{m}$ large beam averages the irregularity of the metal/binder interface. Consequently, the part of the profile between 1700 and $1800 \mu \mathrm{m}$ cannot be considered to study the Fe migration in the binder because it is constituted of a mix of signals coming from the metal, a thin initial corrosion layer, and the binder. For higher distance values, it can be considered that the observations are made in the initial binder as shown by the increase of the Ca content. At these locations, the profile of the Fe content obtained at $t=0$ shows the initial distribution of this element in the binder. The Fe content is very low (note that the XRF detection limit of iron is of 2 orders of magnitude lower than EDS). After 2 hours the Fe content in the binder begins to increase significantly and continuously until the last measurement after 21 hours. For each acquisition time, the profile decreases from the rebar to the outer part of the binder, confirming that the source of the iron is the corrosion of the rebar. Nevertheless, despite this trend, the profiles all show important irregularities. These local increases of the iron content are probably due to larger porosities, and in some case, as for $t=6 \mathrm{~h}$ and $21 \mathrm{~h}$ between 2500 and $2800 \mu \mathrm{m}$, they can still be filled by corrosion product precipitation. Thus, after $21 \mathrm{~h}$, iron has migrated more than $1 \mathrm{~mm}$ from the initial metal/ binder interface. Post mortem analyses performed by SEM-EDS (Fig. 6) confirm this observation. The migration paths of the Fe species in the binder seem to follow in priority the larger cracks and pores. These cracks and pores appear in black before the experiment in Fig. 6; at the end of the experiment, they are completely filled with iron corrosion products.

The micro-XRD patterns obtained in situ at the distance of $1950 \mu \mathrm{m}$ during the experiment on the laboratory rotating anode set-up (Fig. 7) show, after $7 \mathrm{~h} 30 \mathrm{~min}$ of corrosion, the a)
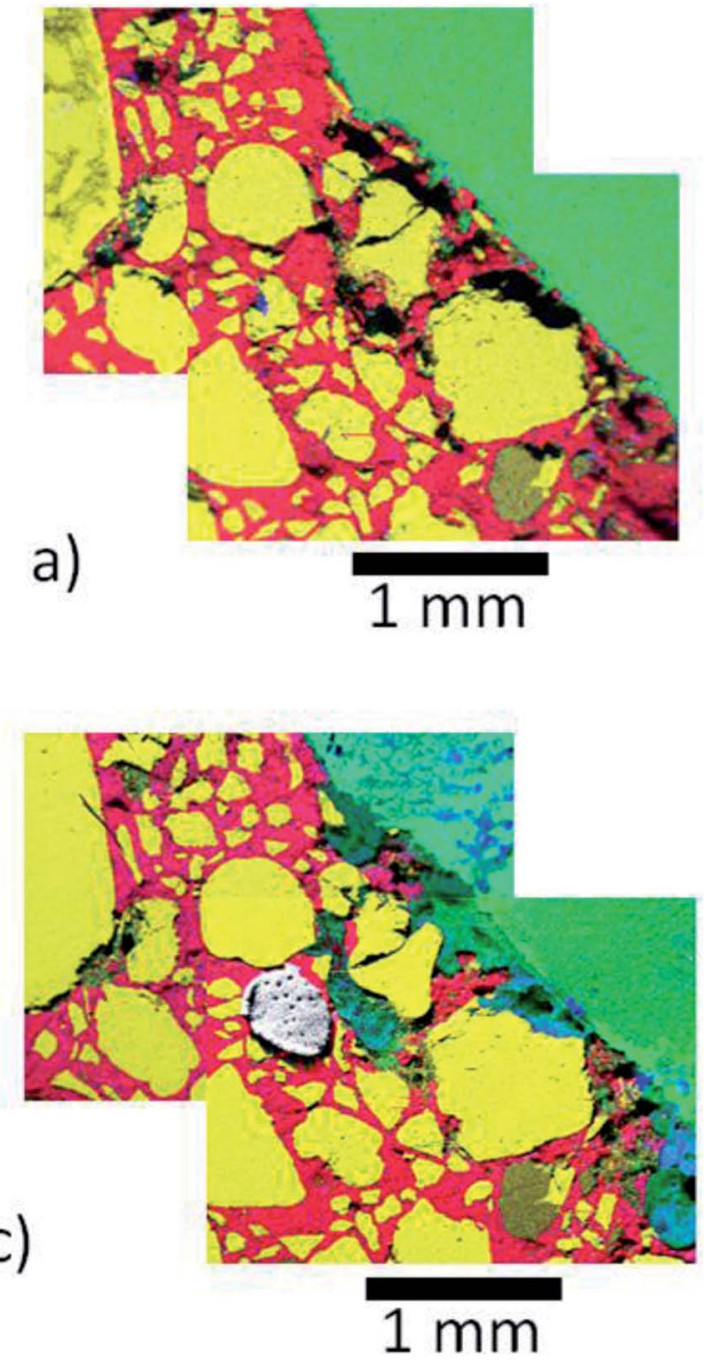

b)
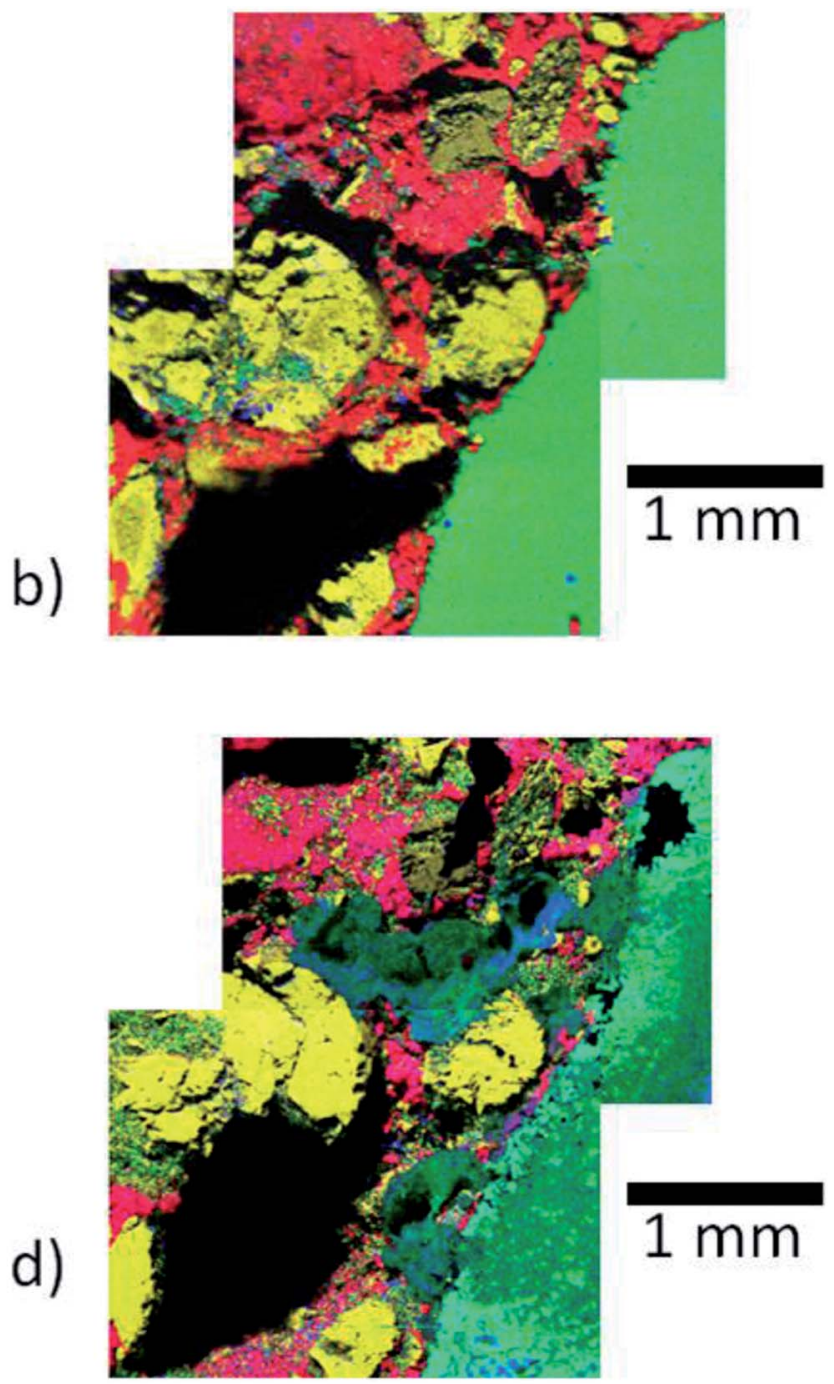

Fig. 6 Cell C02-E03, EDS maps ( $\mathrm{Fe}=$ green, $\mathrm{Ca}=$ red, $\mathrm{Si}=$ yellow, $\mathrm{Cl}=$ blue): (a) \& (b) respectively zones 1 \& 2 before the corrosion; (c) \& (d) respectively zones $1 \& 2$ after the in situ monitoring of the corrosion process showing the presence of iron inside the cement paste. The gray array on (c) is due to an artefact linked to a thick $C$ deposition before the SEM observation. 


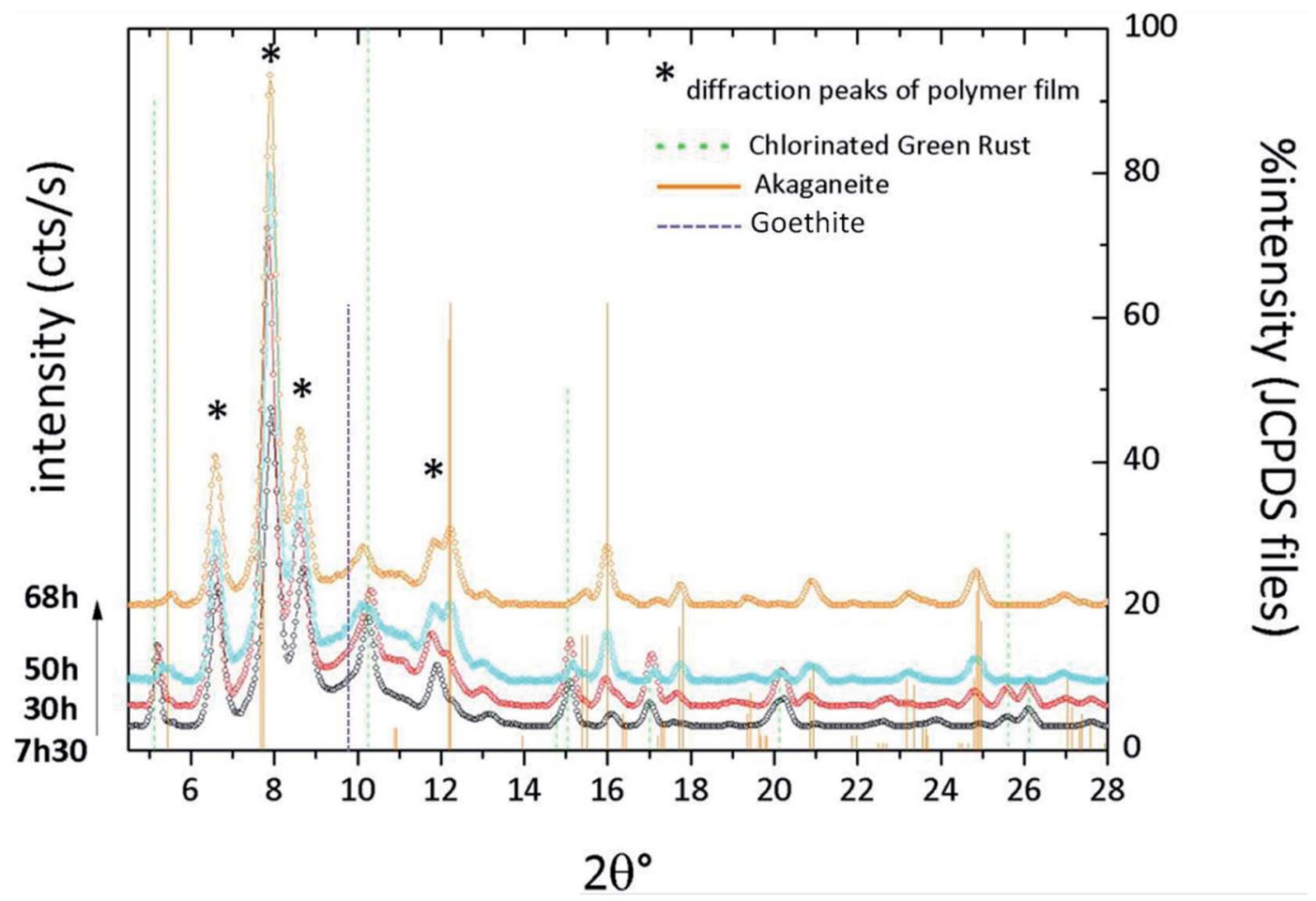

Fig. 7 Cell C07-C01, X-ray diffraction patterns obtained on the laboratory set-up from $7 \mathrm{~h} 30 \mathrm{~min}$ to $68 \mathrm{~h}$ of corrosion.

presence of chlorinated green rust and a minority of akaganeite $(\beta-\mathrm{FeOOH})$. The chlorinated green rust is a compound rarely observed on corrosion products because of its low chemical stability when it is exposed to air and has mainly been studied in the laboratory. ${ }^{21}$ While the green rust is the main product at the beginning of the corrosion process, it seems to progressively disappear in favour of akaganeite. It can be noted that a shoulder at $9.7^{\circ}$ appears and could be due to the presence of goethite $(\alpha-\mathrm{FeOOH})$. After 50 hours the peaks of the green rust are weaker but still present. After 68 hours there is no green rust anymore and akaganeite is the main product detected.

The micro-XRD diffraction maps, obtained on the DiffAbs beamline with a much smaller beam than on the laboratory setup, $1 \mathrm{~h}$ after the beginning of the in situ experiment (Fig. 8(1)), confirm that the main phase formed near the iron rebar is chlorinated green rust. At some locations, spots of akaganeite appear. After 4 hours (not shown here) the same observations are noted, with an increase of the intensities for each phase and a spreading of the green rust precipitation zone towards the external zone farther from the iron rebar. The same phenomenon is observed at 8 hours i.e. akaganeite precipitates locally near the bar, the green rust zone extends and for both phases an increase of the peak intensities attests to the presence of higher amounts. But at the same time some goethite appeared at a farther distance from the steel bar. It has to be noted that during the experiment, it appears that the akaganeite dominance area grows and shifts on the surface of the transverse section of the bars probably due to a local peel off of the adhesive film in contact with the solution. The same observations can be made after 12 and 16 hours of experiment (not shown here). After 20 hours, the green rust starts to disappear whereas akaganeite remains present near the metal and goethite at a farther distance from it. After $32 \mathrm{~h}$ of experiment, the green rust has completely disappeared from the map and the system is stabilized as shown on the $44 \mathrm{~h}$ maps. The following maps show the presence of goethite from 0.6 to 1.6 millimeters from the steel bar. Thus, chlorinated green rust, akaganeite and goethite could be dominant simultaneously in different areas, roughly depending on the distance from the metal/binder interface.

\section{Discussion}

The first step of the experiment is characterized by the capillary penetration of the chlorinated solution. After the saturation of the pore network, $\mathrm{pH}$ indicators placed on the cell indicate a $\mathrm{pH}$ value of 13. In a first approximation it is representative of the $\mathrm{pH}$ of the pore solution imposed by the buffering effect of the binder. Consequently, $\left[\mathrm{OH}^{-}\right]=0.1 \mathrm{~mol} \mathrm{~L}^{-1}$. Moreover, the initial concentration of the $\mathrm{NaCl}$ solution is $0.5 \mathrm{~mol} \mathrm{~L}^{-1}$ and it can be considered that it corresponds to the concentration in the solution saturating the pore network. Lastly, the solution is aerated during all of the experiment.

The micro-XRF profiles show that, in the conditions of the experiments, the iron corrosion products migrate in the pores of the binder before precipitating. After $21 \mathrm{~h}$ of corrosion, this migration process allowed significant quantities of iron to be transported more than $1 \mathrm{~mm}$ away from the binder/ rebar interface. It seems nevertheless as shown on the micro$\mathrm{XRD}$ maps that this migration is hindered by phase 
a

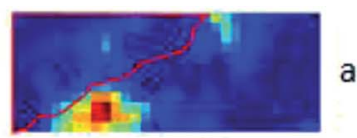

b

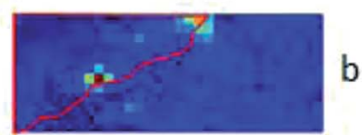

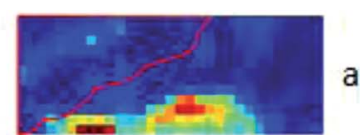

a
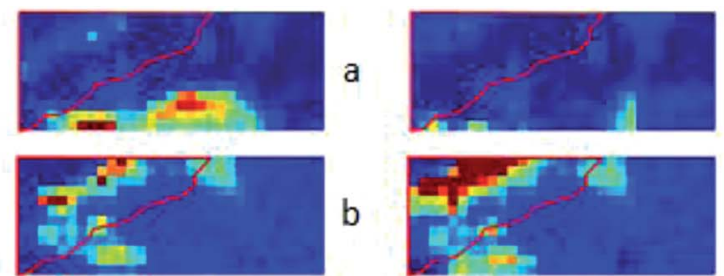

b

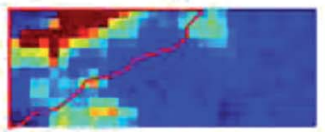

C
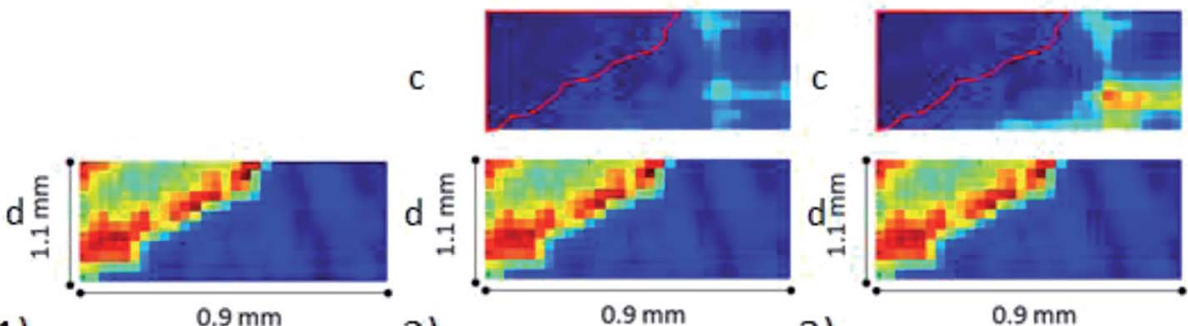

1)

2

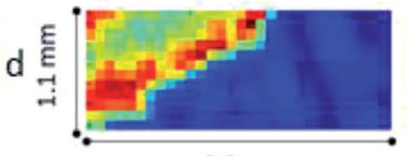

2)

$0.9 \mathrm{~mm}$

3)

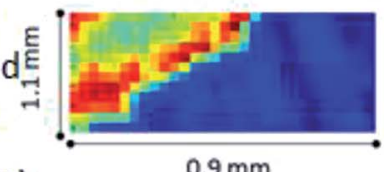

$0.9 \mathrm{~mm}$

a

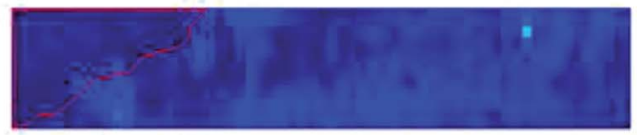

b

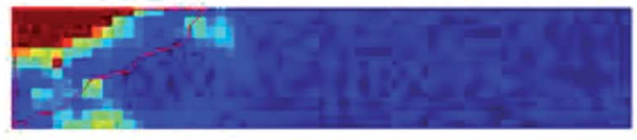

C

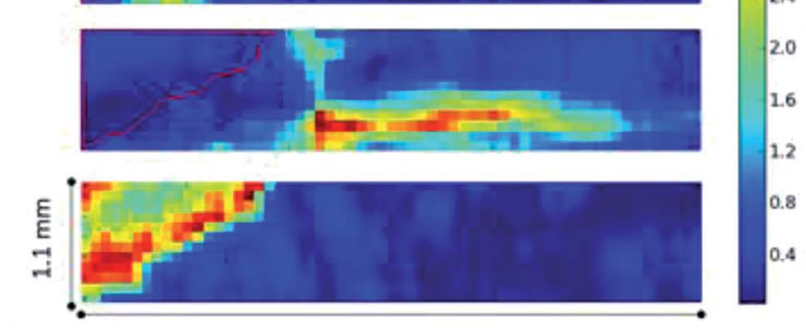

4)

$1.8 \mathrm{~mm}$

Fig. 8 Cell C02-E03, X-ray diffraction maps obtained on the DiffAbs beamline at Synchrotron SOLEIL: distribution of (a) chlorinated green rust; (b) akaganeite; (c) goethite; (d) iron; after (1) $1 \mathrm{~h}$, (2) $8 \mathrm{~h}$, (3) $20 \mathrm{~h}$ and (4) $44 \mathrm{~h}$ of monitoring.

precipitation: the $40 \mathrm{~h}$ maps are similar to the $32 \mathrm{~h}$ ones. To migrate relatively far from the metal/binder interface, iron is dissolved in the pore solution in the form of complexed $\mathrm{Fe}^{2+}$ ions at basic pH. Refait et al. ${ }^{22,23}$ and Rémazeilles et al. ${ }^{21,24}$ studied the evolution of solutions containing $\mathrm{Fe}^{2+}$ and $\mathrm{Cl}^{-}$ compounds that oxidise under aerated conditions. Let us discuss the present results considering these former studies.

These authors discussed the oxidation mechanisms of the $\mathrm{Fe}(\mathrm{II})$ containing phases (obtained by mixing $\mathrm{NaOH}$ and $\left.\mathrm{FeCl}_{2} \cdot 4 \mathrm{H}_{2} \mathrm{O}\right)$ through two parameters: $R=\left[\mathrm{Fe}^{2+}\right] /\left[\mathrm{OH}^{-}\right]$and $R^{\prime}$ $=\left[\mathrm{Cl}^{-}\right] /\left[\mathrm{OH}^{-}\right]$. The diagram of Fig. 9 sums up a part of these results corresponding to "low" oxidation rates, i.e. without adding $\mathrm{H}_{2} \mathrm{O}_{2}$ and obtained in aerated conditions in a stirred solution. It is interesting to note that despite variations of the stirring rate, the time for oxidizing $\mathrm{Fe}^{2+}$ species in aerated conditions is in the same order of magnitude as the one observed in the present study. For example, in ref. 23 for $R^{\prime}=$ 3 , it takes about 4 hours to obtain akaganeite from the initial solution. This time increases with $R^{\prime}$ and can sometimes reach 10 hours. Here, in the pore network of the binder, although $\mathrm{O}_{2}$ can access the solution, it is probable that this access is hindered compared to the stirred solution. Thus, the oxidation duration required to obtain the final product is slightly higher and can reach several tens of hours. However, the evolution paths of the phases precipitated in both the laboratory and cell conditions are very comparable. In the cell experiment it can be supposed in a first approximation that in the pores $R^{\prime}=5$ (i.e. $\left[\mathrm{OH}^{-}\right]=0.1 \mathrm{~mol} \mathrm{~L}{ }^{-1}$ and $\left[\mathrm{Cl}^{-}\right]=0.5 \mathrm{~mol} \mathrm{~L}{ }^{-1}$ ). The evolution path of the phases for $R^{\prime}=5$ shows that the oxidation of $\mathrm{Fe}^{2+}$ should first lead to the formation of $\beta-\mathrm{Fe}_{2}(\mathrm{OH})_{3} \mathrm{Cl}$ and then to the chlorinated green rust $\left(\mathrm{Fe}_{3}{ }^{\mathrm{II}} \mathrm{Fe}^{\mathrm{III}}(\mathrm{OH})_{8}\right]^{+}[-$ $\left.\mathrm{Cl} \cdot n \mathrm{H}_{2} \mathrm{O}\right]^{-}$). The first compound was not observed here: after at least 1 hour, the only detected compound by micro-XRD is the chlorinated green rust. The fact that the first micro-XRD map was acquired $1 \mathrm{~h}$ after the $\mathrm{NaCl}$ introduction could explain the absence of the first transient phase (i.e. it has already disappeared). 


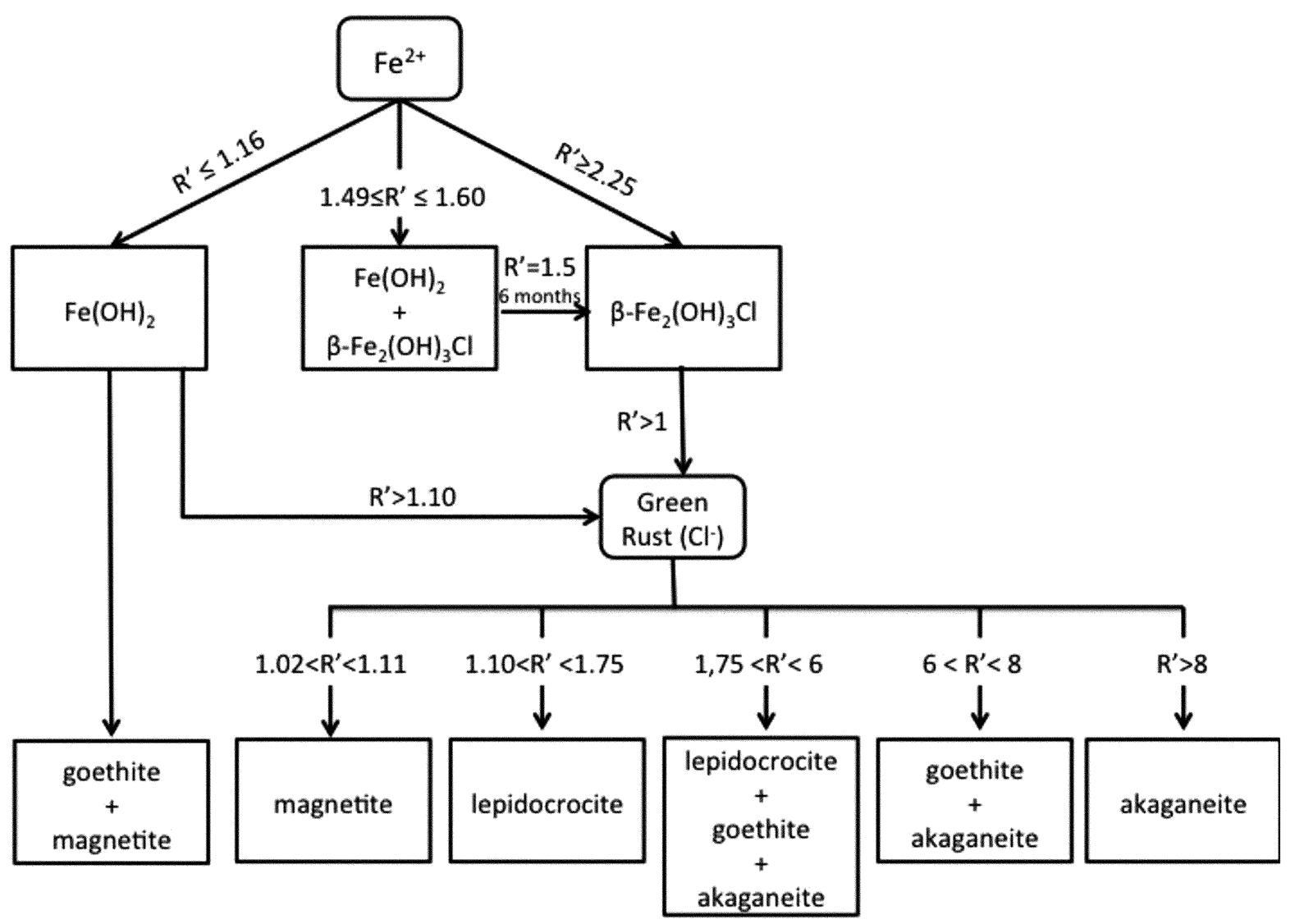

Fig. 9 Summarized diagram of phase formation during the iron oxidation process in chloride medium. $R=R^{\prime} / 2,[\mathrm{NaOH}]=0.4 \mathrm{~mol} \mathrm{~L}^{-1}$. ${ }^{21-24}$

In the following stages of the oxidation process proposed in Fig. 9, the green rust progressively transforms into Fe(III) oxyhydroxides. For $R^{\prime}=5$ the products are a mix of lepidocrocite $(\gamma$ $\mathrm{FeOOH})$, goethite $(\alpha-\mathrm{FeOOH})$ and akaganeite $(\beta-\mathrm{FeOOH})$. Actually Refait et al. ${ }^{22,23}$ indicated that the higher $R^{\prime}$ is, the less lepidocrocite is observed and the more goethite and akaganeite. This is in relatively good agreement with the observations made by micro-XRD mapping for the present study: after $8 \mathrm{~h}$ akaganeite and goethite begin to replace the green rust. After $22 \mathrm{~h}$ the green rust has almost disappeared and is totally transformed after $32 \mathrm{~h}$ into both akaganeite and goethite depending on the location in relation to the steel bar. In the in situ cell, compared to the oxidation processes observed in the laboratory by Refait, Rémazeilles and co-workers for $R^{\prime}=5$, no lepidocrocite is observed. This can be explained by several factors. The first one is that in the cell the dissolved oxygen content could be lower although the conditions are aerated and limit the kinetics of formation of lepidocrocite. Moreover, for the relatively high $R^{\prime}$ parameter, not so far from 6 , the nature of the final phases is also influenced by the parameter $R$. During the studies presented in Fig. 9, $R$ was always fixed as $R^{\prime} / 2$, but other experiments performed by Rémazeilles ${ }^{24}$ showed that for a given $R^{\prime}$, a decrease of $R$ (i.e. a decrease of $\left[\mathrm{Fe}^{2+}\right]$ ) favours the precipitation of goethite versus akaganeite. This could explain at the same time why the precipitation of goethite seems to be more important farther from the metal/binder interface, where the iron concentration is lower, as demonstrated by the XRF profile.
Thus, the following scenario can be proposed to explain the first steps of corrosion at the interface of the bar. The introduction of the solution near the rebar provokes aqueous corrosion of the iron i.e. the solubilisation of ferrous cations at the interface. Despite the aerated conditions, the oxidation kinetics of iron containing species are sufficiently low to allow the migration of $\mathrm{Fe}^{2+}$ species relatively far from the metal/ binder interface during several tens of hours. Considering the concentration of chloride and former results, $\beta-\mathrm{Fe}_{2}(\mathrm{OH})_{3} \mathrm{Cl}$ could have precipitated. These phases could have formed in our experiment during the humidification of the cell because we didn't observe them when the in situ analyses began. Here, only chlorinated green rust was observed. This observation is in good agreement with the $R^{\prime}$ value. The next step observed in situ is the progressive disappearance of the green rust and the concomitant precipitation of akaganeite on the more internal part of the pore and goethite at the external part. In our case, the absence of lepidocrocite could indicate a moderate oxygen content in the solution in the observed zones because this phase is generally identified in more aerated conditions. ${ }^{25}$ The presence of goethite farther from the metal/binder interface is explained by the decreasing $\mathrm{Fe}$ profile, favouring the precipitation of goethite. This precipitation of phases will progressively clog the pores of the pore network, hindering the water penetration in the binder. Consequently, two different consequences are observed here. The first one is linked to the presence of lowdensity chlorinated phases that could provoke an important 
cracking of the binder after precipitation. The second one is linked to the fact that iron can migrate relatively far from the interface. This will diminish the first effect significantly.

\section{Conclusions}

In situ analyses have been performed on a cell constituted of a steel bar in a mortar matrix. The first steps of the steel bar corrosion when the mortar is saturated by a chlorinated solution have been observed using micro-XRF and micro-XRD. These first results highlight the presence of an intermediate $\mathrm{Fe}(\mathrm{II})-\mathrm{Fe}$ (III) corrosion product: a chlorinated green rust which tends to transform into ferric oxyhydroxides such as akaganeite or goethite. The nature of the precipitated phase depends on the local chloride content, the presence of dissolved $\mathrm{O}_{2}$ and the migration of $\mathrm{Fe}^{2+}$ in the pore network of the binder. The presence of the transient phase could have catastrophic consequences on the structure of the binder. Actually, its lower density could lead to the appearance of new cracks after its precipitation. Nevertheless, an interesting result of the in situ measurements is that the oxidation process of $\mathrm{Fe}^{2+}$ species generated by the corrosion process, is relatively slow and takes several tens of hours during which iron, in the form of $\mathrm{Fe}^{2+}$ ions, can migrate several millimeters in the pore network before any precipitation occurs. This could considerably lower the effect of the precipitation of corrosion products at the metal/binder interface and decrease the danger of cracking of the binder by this precipitation because the phases can be distributed in a larger volume.

Further tests have to be performed with various conditions to study the effect of different solution concentrations, especially for chloride. But these first results are a crucial step to better understand the transient processes involved in the degradation in the presence of chlorides of reinforced concrete used for building historical monuments and more largely for any historical building reinforced by iron and steel sealed in hydraulic binders.

\section{Acknowledgements}

The authors would like to acknowledge the LabEx Patrima for funding, the DiffAbs beamline staff for helping to conduct the experiment and the CEA-LECBA team for scientific interactions on the project. We appreciated particularly the contribution of time and effort of Frederic Picca from the instrumental group of Synchrotron SOLEIL who helped in the XRD data treatment.

\section{Notes and references}

1 M. L'Héritier, P. Dillmann, A. Timbert and P. Bernardi, in Nuts and bolts of construction history. Culture, technology and society, ed. R. Carvais, A. Guillerme, V. Nègre and J. Sakarovitch, Picard, Paris, 2012, vol. 2.

2 M. L'Héritier, P. Dillmann and P. Benoit, Hist. Metall., 2010, 44, 21-35.

3 P. Bernardi and P. Dillmann, in De Re Metallica. The uses of metal in the Middle Ages, ed. R. Bork, Ashgate, 2005, vol. 4, pp. 297-315.

4 P. Dillmann, F. Mirambet, S. Reguer and M. L'Heritier, L'Actualité Chimique, 2007, 71-77.

5 D. Neff, E. Marie Victoire, V. L'Hostis, E. Cailleux, L. Vincent, A. Texier, L. Bellot-Gurlet and P. Dillmann, Metalo7, Amsterdam, 2007.

6 E. Marie-Victoire, E. Cailleux and A. Texier, J. Phys. IV, 2006, 136, 305-318.

7 E. Marie-Victoire and A. Texier, Durability of Building Materials and Components 8, Proceedings, 1999, vol. 1-4, pp. 581-592.

8 L. Bertolini, B. Elsener, P. Pedeferri, E. Redaelli and R. B. Polder, Corrosion of Steel in Concrete: Prevention, Diagnosis, Repair, Wiley, 2013.

$9 \mathrm{~K}$. Tuuti, Corrosion of steel in concrete, Swedish Cement and Concrete Research Institute, 1982.

10 G. K. Glass and N. R. Buenfeld, Corros. Sci., 1997, 39, 10011013.

11 A. Demoulin, C. Trigance, D. Neff, E. Foy, P. Dillmann and V. L'Hostis, Corros. Sci., 2010, 52, 3168-3179.

12 Y. Zhao, H. Ren, H. Dai and W. Jin, Corros. Sci., 2011, 53, 1646-1658.

13 D. Neff, J. Harnisch, M. Beck, V. L'Hostis, J. Goebbels and D. Meinel, Mater. Corros., 2011, 62, 861-871.

14 Q. Yuan, C. Shi, G. De Schutter, K. Audenaert and D. Deng, Construct. Build. Mater., 2009, 23, 1-13.

15 H. S. Wong, Y. X. Zhao, A. R. Karimi, N. R. Buenfeld and W. L. Jin, Corros. Sci., 2010, 52, 2469-2480.

16 K. Nakano, K. Akioka, T. Doi, M. Arai, H. Takabe and K. Tsuji, ISIJ Int., 2013, 53, 1953-1957.

17 S. Hirano, K. Akioka, T. Doi, M. Arai and K. Tsuji, X-Ray Spectrom., 2014, 43, 216-220.

18 A. Farci, D. Floris and P. Meloni, J. Cult. Herit., 2005, 6, 5559.

19 F. Baudelet, R. Belkhou, V. Briois, A. Coati and P. Dumas, Oil Gas Sci. Technol., 2005, 60, 849-874.

20 K. Medjoubi, T. Bucaille, S. Hustache, J.-F. Bérar, N. Boudet, J.-C. Clemens, P. Delpierre and B. Dinkespiler, J. Synchrotron Radiat., 2010, 17, 486-495.

21 C. Rémazeilles and P. Refait, Corros. Sci., 2008, 50, 856-864. 22 P. Refait and J. M. R. Génin, Corros. Sci., 1997, 39, 539-553. 23 P. Refait and J. M. R. Génin, Corros. Sci., 1993, 34, 797-819. 24 C. Rémazeilles and P. Refait, Corros. Sci., 2007, 49, 844-857. 25 T. Misawa, K. Hashimoto and S. Shimodaira, Corros. Sci., 1974, 14, 131-149. 